\title{
SINTESIS DAN KARAKTERISASI PIGMEN MERAH BESI(III) OKSIDA DARI SERBUK BESI LIMBAH BUBUT LOGAM
}

\author{
FUthri AZHARI KHALAMUdilah ${ }^{1}$, DEDE SUHENDAR ${ }^{1 *}$, DAN ASEP SUPRIADIN ${ }^{1}$ \\ ${ }^{1}$ Jurusan Kimia, Fakultas Sains dan Teknologi, UIN Sunan Gunung Djati Bandung, \\ Jl. A.H. Nasution No. 105, Bandung \\ *Email korespondensi: dede.suhendar@uinsgd.ac.id
}

\begin{abstract}
Informasi Artikel Abstrak/Abstract
Riwayat Naskah :

Diterima pada 23

Mei 2017

Diterima setelah

direvisi pada 29 Juni

2017

Diterbitkan pada 30

Juni 2017

Kata kunci: Sintesis; pigmen merah hematit; besi(III) oksida; presipitasi;

Limbah bubut dengan kandungan logam berat dapat menyebabkan pencemaran lingkungan jika dibuang secara langsung ke lingkungan tanpa diolah kembali. Limbah tersebut merupakan bahan potensial yang dapat dimanfaatkan karena kandungan utamanya yang sebagian besar merupakan unsur besi. Sintesis pigmen merah digunakan metode presipitasi dengan menggunakan 4 suhu kalsinasi yang berbeda $\left(500,600,700\right.$, dan $\left.800^{\circ} \mathrm{C}\right)$. Karakterisasi hasil sintesis digunakan instrumen $X$-Ray Diffraction (XRD) dan Spektrofotometer Datacolor. Serbuk besi dari limbah bubut logam yang digunakan sebagai sampel mengandung unsur besi (Fe), hasil sintesis diperoleh empat pigmen merah besi(III) oksida dengan fasa hematit dengan rendemen $99,90 \%$ dan dengan intensitas warna merah yang berbeda pada setiap suhu kalsinasi yang digunakan. Serbuk besi limbah bubut logam dapat disintesis menjadi pigmen merah besi(III) oksida (hematit) dengan metode presipitasi dan pigmen merah dengan kalsinasi suhu $700^{\circ} \mathrm{C}$ memiliki intensitas warna merah yang dominan dari ke-3 suhu kalsinasi yang lain.
\end{abstract} limbah bubut besi.

Keywords:

Synthesis; red pigment hematite; iron (III) oxide; precipitation; iron lathe waste.

\begin{abstract}
The synthesis of iron (III) oxide red pigment from metal lathe waste powder has been synthesized. Lathe with heavy metal content can cause environmental pollution if it is discharged directly into the environment without being reprocessed. The waste is a potential material that can be utilized because its main content, which is mostly iron, uses technical grade materials. Red pigment synthesis was used precipitation method by using 4 different calcination temperatures $\left(500,600,700\right.$, and $\left.800^{\circ} \mathrm{C}\right)$. Characterization of the results of the synthesis used XRD instruments and Datacolor spectrophotometers. The iron powder from metal lathe waste which is used as a sample contains iron $(\mathrm{Fe})$, the synthesis results obtained four red iron (III) oxide pigments with hematite phase with yield of $99.90 \%$ and with different red intensity at each calcination temperature used.
\end{abstract}

\section{PENDAHULUAN}

Besi merupakan logam yang paling banyak terdapat di alam. Besi juga diketahui sebagai unsur yang paling banyak membentuk bumi, yaitu kira-kira 4,7 - 5\% pada kerak bumi. Besi adalah logam yang dihasilkan dari bijih besi dan jarang dijumpai dalam keadaan bebas, kebanyakan besi terdapat dalam batuan dan tanah sebagai oksida besi, seperti oksida besi magnetit $\left(\mathrm{Fe}_{3} \mathrm{O}_{4}\right)$ mengandung besi 65\%, hematit $\left(\mathrm{Fe}_{2} \mathrm{O}_{3}\right)$ mengandung $60-75 \%$ besi, limonet $\left(\mathrm{Fe}_{2} \mathrm{O}_{3} \cdot \mathrm{H}_{2} \mathrm{O}\right)$ mengandung $20 \%$ besi dan siderit $\left(\mathrm{Fe}_{2} \mathrm{CO}_{3}\right)$ mengandung $10 \%$ besi [1]. Dalam kehidupan, besi merupakan logam paling biasa digunakan dari pada logam-logam yang lain sebagai paduan logam. Hal ini disebabkan karena harga yang murah dan kekuatannya yang baik serta penggunaannya yang luas. Kegunaan besi yang sangat besar sebagai logam banyak digunakan dalam berbagai bidang industri. Misalnya, sintetis besi oksida yang dapat digunakan sebagai katalis dalam proses redoks dan sebagai pigmen [2]. Selain itu, besi oksida digunakan untuk mewarnai kertas, karet, plastik dan semen, komponen cat, pernis dan enamel, karena berbagai warna (kuning, coklat, dan merah) pigmen yang dapat diperoleh dengan warna yang berbeda dari besi oksida tersebut.

Penggunaan pigmen merah besi oksida dalam dunia industri salah satunya menjadi pemberi warna (filler) dalam formulasi cat, selain sebagai cat dekorasi, besi merah oksida dapat digunakan sebagai cat khusus (tahan temperatur) guna keperluan pelapisan cerobong, pemanas dan pipa.

Besi merah oksida adalah teknologi bahan penting dan memiliki karakter unggul dalam nontoksisitas, stabilitas kimia, daya tahan dan biaya rendah [3]. Sebenarnya, didalam limbah pun masih terdapat kandungan bahan berharga yang apabila didaur ulang dapat memberikan laba ekonomis kepada pengusaha [4]. Salah satu cara penanganan limbah yang sangat menguntungkan 
adalah memanfaatkan bubut logam untuk menjadi barang yang lebih bernilai ekonomis yaitu pigmen merah. Tujuan penelitian ini adalah mensintesis bubut logam menjadi pigmen merah oksida besi.

Ditinjau dari komposisi oksida logam yang dominan, bubut besi terdiri dari logam besi oksida. Kandungan unsur $\mathrm{Fe}$ yang tinggi pada bubut besi merupakan sumber daya potensial untuk dijadikan bahan baku pembuatan pigmen berwarna merah dan hitam yang dapat dijadikan bahan dalam pigmen cat, pelapisan besi dan dapat dijadikan bahan baku pembuatan koagulan berbasis logam. Koagulan berbasis logam $\mathrm{Fe}$ sudah dikenal dan digunakan secara luas dalam pengolahan air. Garam besi akan membentuk gelatin hidroksida logam yang mampu mengendapkan partikel koloid [5].

Dengan demikian, limbah bubut logam cukup banyak dihasilkan dan belum dimanfaatkan secara signifikan, maka dilakukan penelitian terhadap limbah bubut logam tersebut yang memiliki banyak kandungan besi didalamnya untuk dijadikan pigmen warna merah. Penelitian ini dilakukan sintesis dan karakterisasi pigmen merah besi(III) oksida dari serbuk besi limbah bubut logam dengan variasi suhu yang berbeda sesuai dengan range terbentuknya besi merah oksida yaitu suhu $500-800^{\circ} \mathrm{C}$ dan dilihat pembentukan warna merah yang paling baik (dominan) pada suhu yang digunakan sebagai suhu kalsinansi.

\section{EKSPERIMEN}

\section{Material}

Bahan-bahan yang digunakan dalam penelitian ini adalah sampel serbuk besi dari limbah bubut logam, $\mathrm{HCl} 12,06 \mathrm{M}$ (teknis), $\mathrm{NH}_{4} \mathrm{OH} 6,5 \mathrm{M}$ (teknis), $\mathrm{H}_{2} \mathrm{O}_{2} 25 \%$ (teknis), kertas saring teknis, dan akuades.

\section{Instrumentasi}

Pengujian fasa, komposisi kimia, dan warna produk hasil sintesis digunakan X-Ray Diffraction $(X R D)$ tipe PW1710 merek Philips dan Spektrofotometer Datacolor Tipe 400; pengujian komposisi kimia dan konsentrasi unsur pada standar pigmen pembanding digunakan Fluoresensi Sinar-X.

\section{Prosedur Kerja}

\section{Preparasi Sampel}

Sampel bubut logam yang masih bercampur dengan pengotor dipreparasi dengan cara separasi menggunakan magnet dan dilakukan penggerusan dalam Ring Mill hingga ukuran sampel menjadi lebih kecil dan halus, yaitu 150 mesh. Untuk analisa unsur yang terkandung didalam sampel dilakukan analisis menggunakan XRD.

\section{Sintesis Pigmen Merah Besi(III) Oksida}

Sampel serbuk besi halus ditimbang sebanyak \pm 15 gram dan dilakukan pelarutan dengan penambahan asam klorida 12,06 M teknis sebanyak $115 \mathrm{~mL}$ dan dipanaskan dengan suhu $70^{\circ} \mathrm{C}$ hingga sampel larut $( \pm 4 \mathrm{jam})$. Kemudian larutan besi disaring dengan kertas saring teknis dan filtrat ditampung sebagai larutan prekursor yang akan disintesis. Filtrat tersebut kemudian dioksidasi dengan $\mathrm{H}_{2} \mathrm{O}_{2}$ sebanyak $15 \mathrm{~mL}$. Proses pengendapan dilakukan dengan meneteskan amoniak 6,5 M hingga berlebih $( \pm 20 \mathrm{~mL})$ dan terbentuk endapan berwarna coklat kemerahan, endapan yang terbentuk kemudian disaring dengan kertas saring teknis, endapan dicuci dengan akuades panas dan dikeringkan pada temperatur $150^{\circ} \mathrm{C}$ hingga kering. Selanjutnya endapan yang telah kering dilakukan kalsinasi pada variasi temperatur $500,600,700$, dan $800^{\circ} \mathrm{C}$ selama masing-masing 2 jam.

\section{Karakterisasi Hasil Sintesis}

Hasil sintesis pigmen merah besi(III) oksida dengan suhu antara $500-800^{\circ} \mathrm{C}$ tersebut dengan variasi suhu yang berbeda pada 500, 600, 700, $800^{\circ} \mathrm{C}$ dilakukan pengujian fasa menggunakan alat XRD, untuk intensitas warna pigmen merah besi(III) oksida dilakukan analisis dengan Spektrofotometer Datacolor dan untuk pengujian komposisi kimia dan konsentrasi unsur dari standar pigmen merah yang digunakan sebagai pembanding menggunakan alat XRF.

\section{HASIL DAN PEMBAHASAN}

\section{Sintesis Pigmen Merah Besi(III) Oksida}

Sampel limbah bubut diambil dan disampling dari bengkel alat-alat logam, kemudian dipisahkan dari pengotornya seperti tanah dan pasir dengan magnet. Hal ini bertujuan untuk menghilangkan pengotor dan hanya 
mendapatkan sampel berupa limbah bubut yang murni yang akan digunakan sebagai bahan utama dalam pembentukan produk pigmen merah besi(III) oksida. Limbah bubut kemudian dihaluskan dan menghasilkan serbuk besi. Hasil uji awal sampel serbuk besi dengan menggunakan XRD dapat dilihat pada Gambar 1 yang memperlihatkan puncak tertinggi pada $2 \theta$ : 44,$705 ; 65,070$ dan 82,450 . Ketiga puncak ini menunjukkan adanya fase unsur $\mathrm{Fe}$ bersesuaian dengan data literatur PCPDFWIN 06- 0696.

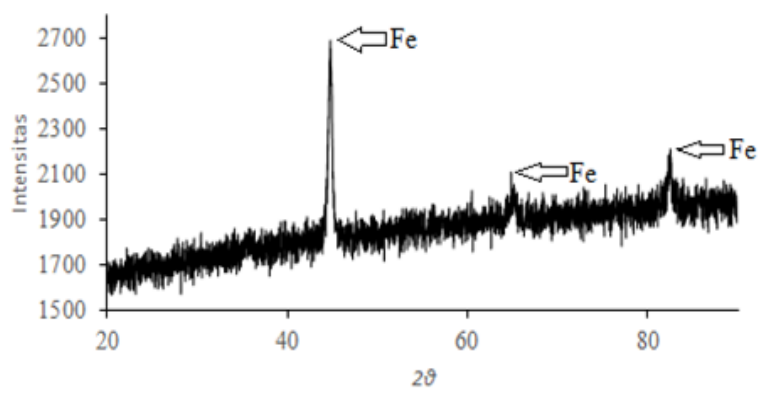

Gambar 1. Difraktogram XRD serbuk besi limbah bubut yang telah dipreparasi

Serbuk besi disintesis menggunakan metode presipitasi dengan pelarut asam klorida teknis dan dioksidasi dengan menggunakan asam peroksida teknis. Massa hasil sintesis pigmen merah besi(III) oksida pada berbagai suhu dapat dilihat pada Tabel 1 di bawah ini.

Tabel 1. Hasil sintesis pigmen merah besi(III) oksida pada berbagai suhu

\begin{tabular}{lll}
\hline $\begin{array}{l}\text { Hasil Pigmen } \\
\text { merah besi(III) } \\
\text { oksida }\end{array}$ & $\begin{array}{l}\text { Massa sampel } \\
\text { serbuk besi } \\
\text { (gram) }\end{array}$ & $\begin{array}{l}\text { Massa produk } \\
\text { hasil sintesis } \\
\text { (gram) }\end{array}$ \\
\hline PM500 & 15,0145 & 15,0125 \\
PM600 & 15,0124 & 15,0108 \\
PM700 & 15,0190 & 15,0165 \\
PM800 & 15,0106 & 15,0089 \\
\hline
\end{tabular}

Dari tabel di atas, dapat disimpulkan bahwa suhu tidak berpengaruh secara signifikan pada massa produk hasil sintesis pigmen merah besi(III) oksida. Serta kandungan yang dimiliki oleh sampel serbuk besi dari limbah bubut logam tersebut sangat berpengaruh pada produk hasil akhir, karena kandungan utamanya yaitu besi yang dominan tanpa ada unsur lain menyebabkan hasil produk yang dihasilkan yaitu besi(III) oksida atau hematit massanya hampir mendekati dari massa awal sampel serbuk besi yang digunakan untuk disintesis dengan persentase sebesar $99,90 \%$
Produk hasil sintesis pigmen merah besi(III) oksida dapat dilihat pada Gambar 2.

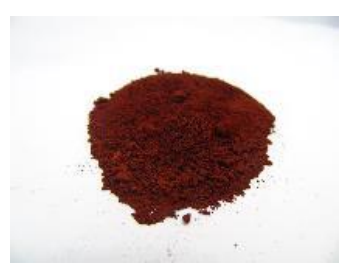

(a)

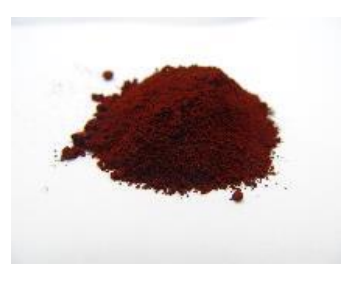

(c)

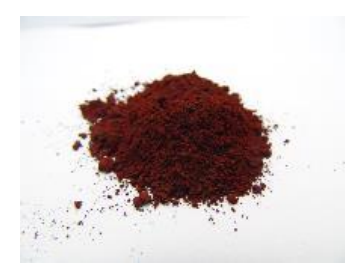

(b)

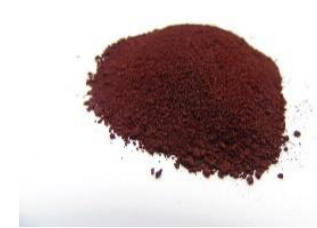

(d)
Gambar 2. Hasil sintesis a) PM500, b) PM600, c) PM700 dan d) PM800

\section{Analisis X-Ray Diffraction (XRD)}

Metode XRD digunakan untuk menentukan jenis atau kandungan senyawa anorganik yang terkandung dalam produk hasil sintesis yang telah dilakukan. Jenis senyawa anorganik dapat diketahui dengan melihat parameter difraksi sinar$\mathrm{X}$ terhadap sampel yang dianalisis. Produk hasil sintesis dikarakterisasi dengan XRD dapat dilhat pada Gambar 3 di bawah ini:

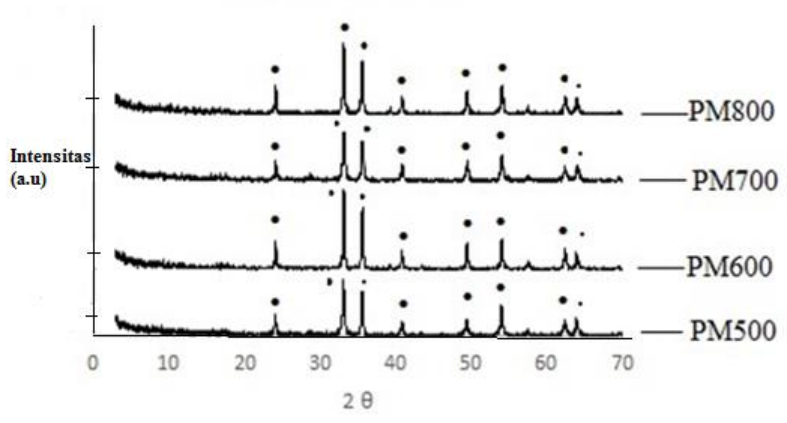

Gambar 3. Difraktogram pigmen merah besi(III) oksida kalsinasi $500-800^{\circ} \mathrm{C}$

Pada puncak tajam yang terbentuk dari difraktogram ke empat hasil sintesis pigmen merah tersebut puncak-puncak tersebut menunjukkan puncak kristal besi(III) oksida atau pola difraksi fasa hematit $\left(\mathrm{Fe}_{2} \mathrm{O}_{3}\right)$ yang terbentuk sesuai dengan literatur $\mathrm{Fe}_{2} \mathrm{O}_{3}$ 33-0664 yang terdapat diinstansi sebagai card data standar, seperti yang ada pada Gambar 4. 


\section{$\langle$ Card Data〉}

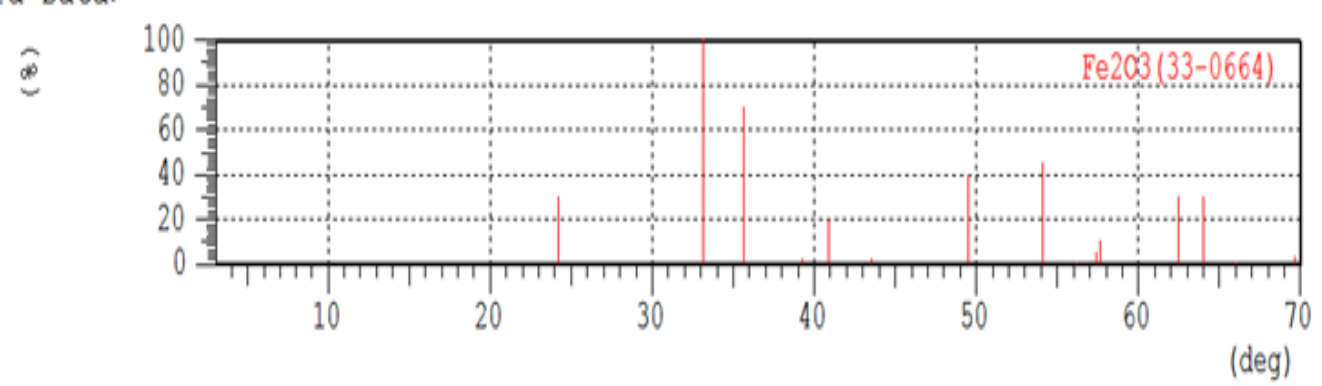

Gambar 4. Card data standar pembanding untuk $\mathrm{Fe}_{2} \mathrm{O}_{3}$

Data hasil XRD yang diperoleh dilakukan perhitungan ukuran kristal dengan menggunakan persamaan scherrer sehingga dapat dihasilkan dan diketahui ukuran kristal pada masing-masing produk hasil sintesis yang dapat dilihat pada Tabel 2.

Tabel 2. Data ukuran kristal pigmen merah

\begin{tabular}{lll}
\hline Nama Sampel & Suhu kalsinasi & Ukuran Kristal \\
\hline PM500 & $500{ }^{\circ} \mathrm{C}$ & $0,5122 \mathrm{~nm}$ \\
PM600 & $600{ }^{\circ} \mathrm{C}$ & $0,5990 \mathrm{~nm}$ \\
PM700 & $700{ }^{\circ} \mathrm{C}$ & $0,6541 \mathrm{~nm}$ \\
PM800 & $800^{\circ} \mathrm{C}$ & $0,7496 \mathrm{~nm}$ \\
\hline
\end{tabular}

Dari tabel di atas, menunjukkan pengaruh suhu kalsinasi terhadap ukuran partikel, dengan penggunaan suhu kalsinasi yang tinggi yaitu diatas suhu $500^{\circ} \mathrm{C}$ dapat dihasilkan ukuran partikel kristal yang bersifat nanopartikel yaitu ukuran nanometer.

\section{Analisis Spektrofotometer Datacolor}

Analisis dengan menggunakan Spektrofotometer Datacolor termasuk ke dalam analisa kuantitatif yang bertujuan untuk mengetahui intensitas warna yang direfleksikan pada panjang gelombang cahaya tampak (visible) yaitu 400-700 nm, nilai refleksi yang diperoleh dari warna yang diukur kemudian diubah menjadi data CIELAB. Berdasarkan warna primer yaitu merah, kuning, hijau dan biru. Pengukuran warna ini dibandingkan dengan standar yang telah tersedia di instansi dan sebagai standar yang biasa digunakan untuk keperluan warna cat.

Berdasarkan Tabel 3 dapat dilihat bahwa nilai hasil pengukuran warna yang diperoleh pada sampel dan standar yang telah dianalisa dapat dipetakan (diplotkan) pada sumbu diatas sesuai dengan nilai positif dan negatifnya. Kemudian dihasilkan kesimpulan dan dibandingkan dengan standar yang digunakan. Setelah diplotkan pada ruang warna tersebut hasil pengukuran pada standar pigmen merah menunjukkan kecerahan terang dengan $\mathrm{DL}^{*}$ positif, nilai $\mathrm{Da}^{*}$ positif sehingga intensitas warna berada di warna merah menuju hijau dan nilai $\mathrm{Db}^{*}$ positif yang menunjukkan intensitas warna kuning menuju biru sehingga dapat dikatakan jika standar pigmen merah memiliki intensitas warna merah dengan campuran warna kuning. Kedua warna terakhir ini merah dan paduannya dengan sedikit kuning seringkali muncul dalam sintesis pigmen merah dari oksida besi $[6,7]$.

Tabel 3. Hasil pengukuran intensitas warna pada sampel dan standar

\begin{tabular}{lllll}
\hline $\begin{array}{l}\text { Nama } \\
\text { Sampel }\end{array}$ & DL* & Da* & $\mathrm{Db}^{*}$ & $\mathrm{DE}$ \\
\hline PM500 & 8,61 & $-11,95$ & $-8,06$ & 16,79 \\
PM600 & 5,62 & $-9,34$ & $-6,41$ & 12,65 \\
PM700 & 4,96 & $-8,97$ & $-3,91$ & 10,98 \\
PM800 & 5,07 & $-10,29$ & $-7,07$ & 13,47 \\
Standar & $-1,00 / 1,00$ & $-1,00 / 1,00$ & $-1,00 / 0,70$ & 1,00 \\
\hline
\end{tabular}

Sedangkan posisi intensitas warna yang dihasilkan dari data sampel menunjukkan bahwa posisi intensitas warna sampel memiliki kecerahan terang karena nilai DL* positif, dengan $\mathrm{Da}^{*}$ negatif yang menunjukkan intensitas warna yang dimiliki sampel yaitu warna hijau menuju merah dan nilai $\mathrm{Db}^{*}$ negatif menunjukkan intensitas warna biru menuju hijau sehingga dapat ditarik kesimpulan jika sampel yang diukur dan dibandingkan dengan standar memiliki intensitas warna yang kurang merah dengan campuran warna biru. Warna merah yang dominan dapat dilihat dari data standarPM yang digunakan yaitu memiliki total nilai $\mathrm{DE}^{*}$ sebesar 1,00 dan nilai $\mathrm{DL}^{*}, \mathrm{Da}^{*}, \mathrm{Db}^{*}$ maksimum 1,00 - minimum 1,00 .

Hasil yang diperoleh pada pengukuran perbedaan warna sampel yang paling mendekati nilai standar ada pada sampel PM700 dan PM600, karena memiliki nilai $\mathrm{DE}^{*}$ yang tidak terlalu jauh yaitu 10,98 dan 12,65 dalam range warna 
memiliki ketakhinggaan sehingga hasil yang diperoleh bisa dikatakan mendekati standar yang memiliki $\mathrm{DE}^{*}$ 1,00 dibandingkan dengan nilai DE* pada PM500 dan PM800.

\section{Analisis X-Ray Fluorescence (XRF)}

Analisis dengan menggunakan instrumen XRF digunakan untuk menganalisis komposisi kimia secara kuantitatif dan konsentrasi unsur secara kualitatif pada sampel yang diukur. Hasil pengukuran komposisi standar pigmen merah hematit pada XRF dengan metode soil yaitu pada Tabel 4 di bawah ini.

Tabel 4. Hasil uji XRF metode soil

\begin{tabular}{cccc}
\hline $\begin{array}{c}\text { Nama } \\
\text { unsur }\end{array}$ & $\begin{array}{c}\text { Persentase } \\
\text { sebagai unsur } \\
(\%)\end{array}$ & $\begin{array}{c}\text { Nama } \\
\text { Senyawa }\end{array}$ & $\begin{array}{c}\text { Persentase } \\
\text { sebagai } \\
\text { senyawa (\%) }\end{array}$ \\
\hline $\mathrm{Fe}$ & $56,2 \%$ & $\mathrm{Fe}_{2} \mathrm{O}_{3}$ & $80,27 \%$ \\
$\mathrm{Ti}$ & $0,11 \%$ & $\mathrm{TiO}_{2}$ & $0,18 \%$ \\
$\mathrm{Sb}$ & $0,08 \%$ & $\mathrm{Sb}_{2} \mathrm{O}_{3}$ & $0,09 \%$ \\
$\mathrm{Cr}$ & $0,06 \%$ & $\mathrm{CrO}_{3}$ & $0,11 \%$ \\
$\mathrm{Cu}$ & $0,05 \%$ & $\mathrm{CuO}$ & $0,06 \%$ \\
$\mathrm{Cd}$ & $0,03 \%$ & $\mathrm{CdO}$ & $0,03 \%$ \\
$\mathrm{Zn}$ & $0,02 \%$ & $\mathrm{ZnO}$ & $0,02 \%$ \\
$\mathrm{Mo}$ & $0,01 \%$ & $\mathrm{MoO}$ & $0,01 \%$ \\
$\mathrm{Sr}$ & $0,004 \%$ & $\mathrm{SrO}$ & $0,004 \%$ \\
$\mathrm{As}$ & $0,002 \%$ & $\mathrm{As}_{2} \mathrm{O}_{3}$ & $0,003 \%$ \\
$\mathrm{L.E}$ & $43,4 \%$ & $\mathrm{Senyawa}_{3}$ & $19,18 \%$ \\
& \multicolumn{3}{c}{ selain } \\
& \multicolumn{3}{c}{ oksida } \\
\end{tabular}

Hasil uji XRF dengan menggunakan metode soil untuk menunjukkan jenis unsur kimia yang terkandung dalam standar yang dianalisa, dari pengukuran standar pigmen merah dengan dominasi warna merah terang tersebut sebagian besar terkandung besi yang jumlahnya lebih dari $50 \%$ sehingga warna merah terang yang dominan tersebut diperoleh dari warna merah khas besi hematit yaitu besi(III) oksida. Selanjutnya persentase kandungan terbesar kedua dipengaruhi oleh unsur seperti $\mathrm{Mg}, \mathrm{Al}, \mathrm{Si}, \mathrm{P}, \mathrm{S}$, dan $\mathrm{Cl}$ yang termasuk kedalam light element. Unsur-unsur penyusun yang lainnya dalam sampel standar tersebut yang dapat mempengaruhi warna pigmen merah yaitu seperti $\mathrm{Ti}, \mathrm{Sb}, \mathrm{Cr}, \mathrm{Cu}, \mathrm{Cd}, \mathrm{Zn}, \mathrm{Mo}$, $\mathrm{Sr}$, dan As dengan persentase yang kecil sehingga kecerahan warna merah dalam standar pigmen merah tersebut dapat dipengaruhi oleh unsur lain sebagai komponen penyusunnya hingga persentase komponennya berjumlah total $\pm 99,9 \%$.

Tabel 5. Hasil uji XRF metode alloy

\begin{tabular}{cc}
\hline Nama unsur & Persentase (\%) \\
\hline $\mathrm{Fe}$ & $91 \%$ \\
$\mathrm{Si}$ & $7,3 \%$ \\
$\mathrm{Al}$ & $1,3 \%$ \\
$\mathrm{Ti}$ & $0,14 \%$ \\
$\mathrm{Cu}$ & $0,11 \%$ \\
$\mathrm{Cr}$ & $0,07 \%$ \\
$\mathrm{Ni}$ & $0,04 \%$ \\
$\mathrm{Mo}$ & $0,02 \%$ \\
$\mathrm{Nb}$ & $0,02 \%$ \\
\hline
\end{tabular}

Tabel 5 menunjukkan hasil uji XRF menggunakan metode alloy sebagai analisa pendukung dari metode sebelumnya yang hanya dapat mendeteksi jenis unsur yang terkandung salam standar pigmen merah, sehingga metode alloy ini dapat memperjelas hasil analisis komposisi dan konsentrasi dengan menggunakan instrumen XRF. Hasil uji XRF pada sampel standar pigmen merah hematit tersebut menunjukkan konsentrasi unsur kimia besi yang sangat besar dan paling dominan karena memiliki presentase $91 \%$, hasil ini menunjukkan bahwa warna merah yang paling dominan dan khas memang ditunjukkan oleh kandungan besi dan itu berasal dari warna khas besi yaitu berwarna merah. Kemudian kecerahan dari dominasi warna merah tersebut dapat dipengaruhi oleh unsur kimia lain yang terkandung dalam standar yaitu seperti $\mathrm{Si}, \mathrm{Al}, \mathrm{Ti}, \mathrm{Cu}, \mathrm{Cr}, \mathrm{Ni}, \mathrm{Mo}$, dan $\mathrm{Nb}$ dengan komposisi yang melengkapi hingga kandungannya menjadi $100 \%$.

\section{SIMPULAN}

Dari hasil penelitian ini dapat ditarik kesimpulan sebagai berikut:

1. Pigmen merah besi(III) oksida atau hematit dapat disintesis dari serbuk besi yang berasal dari limbah bubut logam,

2. Sintesis pigmen merah besi(III) oksida dapat dilakukan dengan metode presipitasi dengan suhu kalsinasi antara $500-800^{\circ} \mathrm{C}$, dan

3. Pigmen merah besi(III) oksida hasil sintesis dengan suhu kalsinasi $700^{\circ} \mathrm{C}$ memiliki intensitas warna merah yang lebih tinggi dan dominan warna merahnya dari pigmen merah besi(III) oksida dengan suhu 500, 600, dan $800^{\circ} \mathrm{C}$. 


\section{UCAPAN TERIMA KASIH}

FHK mengucapkan terima kasih kepada Laboratorium Pengujian Puslit Tekmira atas diskusi interpretasi pola difraksi sinar-X dan Laboratorium Puslit Fisika, Puspiptek LIPI, Serpong atas diskusi metode XRF alloy.

\section{REFERENSI}

[1] Manahan Stanley E, Enviromental Chemistry.: CRC Press LLC, 2000.

[2] P Belleville, J P Jolivet, and E Tronc, "Iron Oxide: From Molecular Cluster to Solid," Journal of Colloid and Interface Science, vol. 150, pp. 453-460, 1992.

[3] Blucher E Lee J, Quimica Inorgaica Nao Tao Concisa., 1999.
[4] I S, R Y, and P J, "Pengambilan kembali krom dari limbah padat elektroplating," vol. IV, p. 4, 1998.

[5] Corrbit R.A, Standard Handbook of Enviromental Engineering.: The Mc GrawHill Companies, 2004.

[6] T Laskelä and M Laskelä, "Preparation of Yellow and Red Iron Oxide Pigment From Iron (II) Sulfate by Alkali Precipitation," Thermochimica Acta, vol. 77, pp. 177-184, 1984.

[7] S Zheng and Q Zhang, "Surface-modification of Fine Red Iron Oxide Pigmen," China Particuology, vol. 1, no. 4, pp. 176-180, 2003. 